\title{
Mapping of Central Pivot Irrigation in the Hydrographic Basin of the Goiano Tributaries of the Araguaia River
}

\author{
Franciele de Freitas Silva ${ }^{1}$, Adriana Rodolfo da $\mathrm{Costa}^{2}$, Pedro Rogerio Giongo ${ }^{2}$, Luciane de Souza Pereira ${ }^{3}$, \\ Wagner de Freitas Silva ${ }^{4}$, Thomas Jefferson Cavalcante ${ }^{1}$, Victor Hugo Moraes ${ }^{1}$, \\ Bruno Henrique Tondato Arantes ${ }^{1} \&$ Janyne Moura dos Santos ${ }^{1}$ \\ ${ }^{1}$ Postgraduate Program in Agrarian Sciences-Agronomy, Goiano Federal Institute, Rio Verde, Goiás, Brazil \\ ${ }^{2}$ State University of Goiás, Santa Helena, Goiás, Brazil \\ ${ }^{3}$ Postgraduate Program in Applied Engineering and Sustainability, Goiano Federal Institute, Rio Verde, Brazil \\ ${ }^{4}$ Information System Course, State University of Goiás, Santa Helena, Brazil \\ Correspondence: Franciele de Freitas Silva, Federal Institute Goiano, Rio Verde, GO, Brazil. Tel: \\ 55-649-9213-7226. E-mail: franciellefreittas@hotmail.com
}

Received: April 29, 2019

doi:10.5539/jas.v11n14p65
Accepted: June 13, 2019

Online Published: August 31, 2019

URL: https://doi.org/10.5539/jas.v11n14p65

\begin{abstract}
The use of irrigation has expanded and favored agricultural productivity in recent years. The mapping through remote sensing has contributed to the monitoring of irrigated areas. In this sense, the objective of this study was to evaluate the central pivotal evolution in terms of location by municipalities, micro basins, soils and slope in the Goian tributary watershed of the Araguaia River State of Goiás. Data were available between 2000 and 2016. Irrigated areas were surveyed through the database available in the Geographical Information System of the State of Goiás (SGEI). The vector and raster data were manipulated using the Qgis v software. 2.18.26 (QGIS Development, 2019). The pivots were counted through the statistical function of the software. From the shape SGEI available in the soil map of classes is generated by categorizes tion of soil types. The declivity map was generated from raster files acquired through the Brazilian Geo morphological Database (INPE, 2017). The slope classes (\%) were extracted with slope tool. There is an increase of more than $95 \%$ in the number of pivots and irrigated area between the years 2000 and 2016. The central pivots are more concentrated in the central region of the Red and Red-Light basins. The highest concentration of central pivots occurred in the municipality of Jussara. The pivots are located predominantly in an Oxisol area with a slope of 3 to $13 \%$.
\end{abstract}

Keywords: irrigated agriculture, micro-basins, water resources

\section{Introduction}

The expansion of irrigation and better management of existing water supplies can contribute to the increase of food production, playing an increasingly important role in agricultural production (Christofidis, 2013; Darko et al., 2015). The central pivot system is one of the most used, besides water can also be used for the application of fertilizers, insecticides and fungicides (Guimarães \& Landau, 2014).

Irrigation is an activity that is in the process of expansion and should increase $20 \%$ (40 million ha) by 2030 , particularly in developing countries (Darko et al., 2015). The estimated potential for growth in the world area with irrigation systems is about 180 million hectares, which potential Brazilian areas represent about 25 million hectares for sustainable development in new areas (Christofidis, 2013).

Estimated by FAO (2016), the world population by 2050 is expected to be over 9 billion people (FAO), and food production will also have to increase by $70 \%(\mathrm{FAO}, 2016)$. The great challenges to be faced are enormous, involving the work of various sectors. It can still be mentioned that in the last 50 years, the capacity of food production increased between 2.5 to 3 times, and the main drivers are science and technology, as well as food production security, such as irrigation in production areas.

Irrigation is a technique capable of increasing the productivity and quality of agricultural products (Kirchner et al., 2019; Landau, Guimarães, \& Sousa, 2014). Irrigated agriculture accounts for $40 \%$ of harvests and uses about $70 \%$ of freshwater in the world (FAO, 2018). Due to the need to produce more and more food, the expansion of 
irrigated areas and agricultural intensification can affect water resources (Pereira Júnior Ferreira \& Miziara, 2017). Thus, it is important to understand the local dynamics regarding the advance of irrigation to better manage natural resources.

Geographic information systems (GIS) and remote sensing are important tools for the monitoring of irrigated agriculture with central pivot (Christofidis, 2013). The use of satellite images can help identify irrigated areas, especially with central pivot systems because these areas are easily identified through visual analysis of the images because they are circular in shape (Ferreira et al., 2011).

The mapping of irrigated areas by central pivot is presented as an alternative to fill information deficiencies in relation to agriculture (Ferreira et al., 2011). Geotechnologies can help monitor agricultural expansion and successive changes in agricultural space, as well as monitoring water resources and monitoring compliance with legislation (Mascarenhas, M. E. Ferreira, \& L. G. Ferreira, 2009).

The objective of this study was to evaluate the central pivotal evolution regarding the location by municipalities, microbasins, soils and slope in the basin of the Araguaia River, Goiás state.

\section{Material and Methods}

The study area comprises the basin of the tributaries of the Araguaia River, which originates in the Serra do Caiapó in the state of Goiás, Mato Grosso and Mato Grosso do Sul states (Mascarenhas, M. E. Ferreira, \& L. G. Ferreira, 2009). It is located between the coordinates $53^{\circ} 00^{\prime} 00^{\prime \prime} \mathrm{W}, 49^{\circ} 12^{\prime} 00^{\prime \prime} \mathrm{W}$ and $18^{\circ} 00^{\prime} 00^{\prime \prime} \mathrm{S}, 12^{\circ} 36^{\prime} 00^{\prime \prime} \mathrm{S}$ (Figure 1).

The vector data of the central pivotal areas, delimitation of the municipalities, soil classes and otto of the basin were acquired together with a database available in the Goiás State Geoinformation System (SIEG, 2019). Including the pivots mapped on Landsat $5 \mathrm{TM}$ satellite imagery conducted by the Mauro Borges Institute and the State Secretariat for the Environment and Water Resources (SEMARH), currently Secretariat for the Environment, Water Resources, Infrastructure, Cities and Metropolitan Affairs of the State of Goiás (SECIMA) for the years 2000, 2006 and 2012. For the year 2016 the pivots vectored and georeferenced by the Geology and Mining Superintendency of the satellite Landsa t 7 ETM + in 2003 and Landsat 8 OLI sensor.

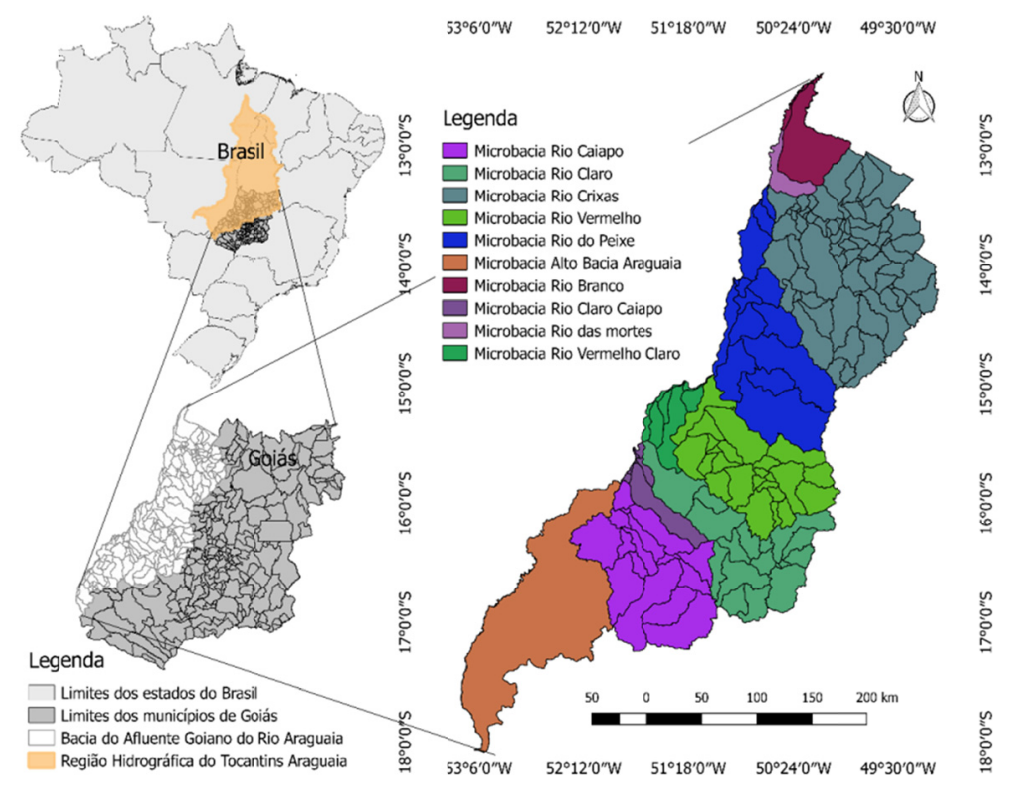

Figure 1. Location map of the basin of the tributaries of the Araguaia-GO River

The data available between 2000 and 2016 were used, and the central pivots were analyzed in the years 2000, 2003, 2006, 2012 and 2016. The vector data were manipulated using Qgis v. 2.18.26 (QGIS Development, 2019). From the table of attributes and the spatial position with the map otto basins of Goiás made available by (SGEI, 2019) carried out by the Superintendence of Geology and Mining-SIC, it was identified the basin of the Araguaia River and the microbasins that composed of the tributary s was performed the cut of the study area. 
The municipalities in the study area were cut by overlapping the clipping of the river basin region of the Araguaia River tributary with the municipal grid. The central pivot counts by municipality and microcatchments were performed through the statistical function in Qgis software 2.18.26.

From soil data provided by (SGEI, 2017) conducted by the Environmental Agency of Goiás in 2005, the soil class map was obtained. The cut was made from the shape of the pivots of the state of Goiás, the cut of the basin of the tributaries of the Araguaia River and the municipalities. The similar lasses $\mathrm{C}$ were joined by attribute table using the joining tool features and categorized by menu properties tab styles to generate the map soil types.

The slope map was generated from scenes from NASA's Shuttle Radar Topography Mission (SRTM) mission. The raster files were acquired through the TOPODATA Geomorphological Database of Brazil (INPE, 2017) with spatial resolution of $30 \mathrm{~m}$. After the acquisition of the scene was changed the coordinate reference system for WGS UTM zone 22S. The slope classes (\%) were extracted in sequence with the Slope tool according to the classification in Table 1.

Table 1. Classes of slope and relief type

\begin{tabular}{llll}
\hline Declivity & & & Relief \\
\cline { 1 - 2 } Class & (\%) & & Type \\
\hline A & 0 to 3 & & Plan \\
B & 3 to 8 & & Soft wavy \\
C & 8 to 13 & & Moderately wavy \\
D & 13 to 20 & & Wavy \\
E & 20 to 45 & & Wavy fort \\
F & $>45$ & Montainous and steep \\
\hline
\end{tabular}

Source: Adapted from Ramalho-Filho and Beek (1995).

\section{Results and Discussions}

The survey carried out through the vector files in the SGEI database indicated that between 2000 and 2016, there was a significant increase in the number of pivots installed in the region, as well as in the irrigated areas (Figure $2 \mathrm{~A}$ and $2 \mathrm{~B}$ ). In 2000 the basin had about 135 pivots occupying an area of approximately 14667.00 hectares. Over the years there has been an evolution of more than $95 \%$ in the number of pivots reaching 265 pivots in 2016 reaching 28684.82 hectares of irrigated area.

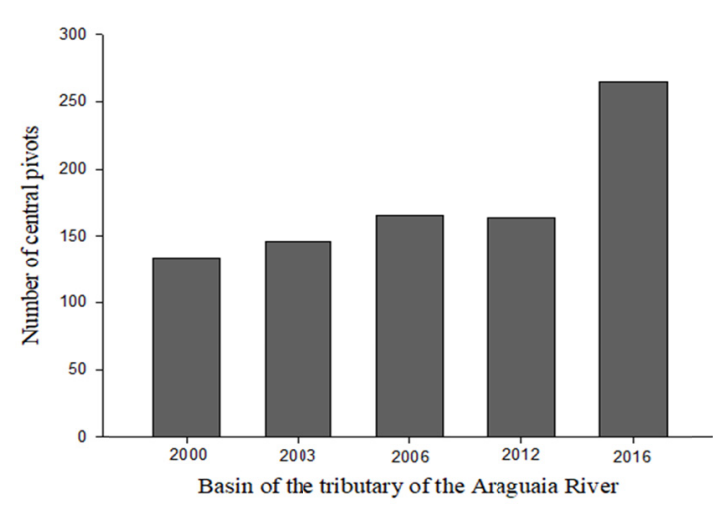

(A)

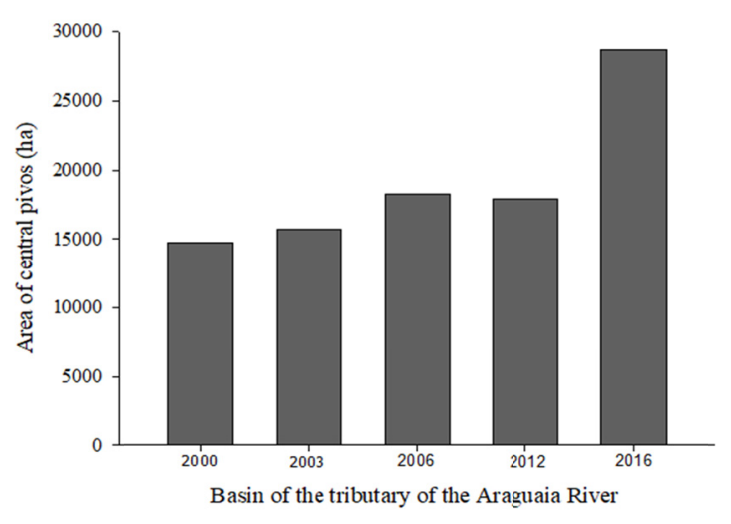

(B)

Figure 2. Number of central pivots (A); Irrigated area (B) in the hydrographic region of the Araguaia River tributary of the years 2000 to 2016

The microbasins of the Rio Vermelho and Vermelho-Claro have the highest number of central pivots (Table 2A and 2B). For the years 2000, 2003, 2006, 2012 and 2016, this region presented the approximate percentage of 75; $70 ; 65 ; 62$ and $68.30 \%$ of installed pivots. With the evolution of the irrigated area, this region presented more than $60 \%$ of the concentration of installed pivots, on average 118.4 equipments considering all evaluated years. 
Table 2. Number of central pivots in the microbasins of the Basin of the Araguaia River

\begin{tabular}{llllll}
\hline \multirow{2}{*}{ Microbasins } & \multicolumn{5}{c}{ Number of Central Pivots } \\
\cline { 2 - 5 } & 2000 & 2003 & 2006 & 2012 & 2016 \\
\hline High Araguaia Basin & 5 & 5 & 4 & 3 & 3 \\
Caiapo River & 3 & 5 & 3 & 2 & 5 \\
Clear-Caiapo River & 7 & 8 & 10 & 11 & 11 \\
Clear River & 3 & 5 & 8 & 9 & 14 \\
Red-Clear River & 23 & 23 & 26 & 32 & 71 \\
Red River & 77 & 79 & 82 & 69 & 110 \\
Fish River & 8 & 11 & 17 & 15 & 21 \\
Crixas River & 7 & 10 & 15 & 22 & 30 \\
Death River & 0 & 0 & 0 & 0 & 0 \\
White River & 0 & 0 & 0 & 0 & 0 \\
Total & 133 & 146 & 165 & 163 & 265 \\
\hline
\end{tabular}

Most of the microbasins presented increased irrigated area over the years, except for the Alto Bacia Araguaia microbasin, which presented a decrease of $67.15 \%$ (Table 3 ). The evaluation of number and area irrigated by central pivot systems using geographic information systems and geoprocessing has also been reported in other studies. In the State of Minas Gerais for the cadastral mapping of the central pivot irrigated areas, $47 \%$ of the pivots in this study (1.828 systems) irrigate areas between 50 and 100 hectares and that expressive numbers (1.277) of pivots irrigate smaller areas and that few units irrigate areas larger than 150 hectares (Ferreira et al., 2011). In Rio Grande do Sul, it was reported the identification and quantification of areas irrigated by central pivot, by river basins and by municipalities in which the central pivots had an average size of 63.66 ha (Martins et al., 2016).

Table 3. Area irrigated by central pivots in the microbasins of the basin of the tributary of the Araguaia River

\begin{tabular}{llllll}
\hline \multirow{2}{*}{ Microbasins } & \multicolumn{5}{c}{ Area (hectare) } \\
\cline { 2 - 6 } & 2000 & 2003 & 2006 & 2012 & 2016 \\
\hline High Araguaia Basin & 433.61 & 216.25 & 454.70 & 291.17 & 291.17 \\
Rio Caiapó & 270.00 & 354.80 & 255.34 & 218.66 & 461.87 \\
Rio Claro-Caiapó & 799.85 & 921.60 & 1148.76 & 1189.52 & 1189.44 \\
clear river & 331.10 & 393.03 & 503.09 & 545.49 & 750.14 \\
Rio Vermelho-Caiapó & 2653.79 & 2765.05 & 2963.73 & 3633.33 & 8424.23 \\
Red River & 8694.88 & 8782,34 & 9224.77 & 7856.68 & 11936.5 \\
Rio do Peixe & 784.89 & 1135.19 & 1920,26 & 1578.14 & 2363,10 \\
Rio Crixas & 698.70 & 1051.8 & 1699.82 & 2501.94 & 3268.37 \\
Rio das Mortes & 0 & 0 & 0 & 0 & 0 \\
White River & 0 & 0 & 0 & 0 & 0 \\
Total & 14666.82 & 15620.06 & 18170.47 & 17814.93 & 28684.82 \\
\hline
\end{tabular}

Of the 54 municipalities located in the study area, 24 presented areas irrigated by central pivot (Table 4). Municipalities such as Caiapônia and São Luis dos Montes Belos presented irrigated area only in the year 2016. The municipality of Jussara presented the highest number of pivots and irrigated area over the years, with highlight for the years 2012 to 2016 that there was an increase of $63.7 \%$ in the number of pivots. This expressive number of pivots in Jussara may be associated mainly with its proximity to the Araguaia River bed, that is, the availability of water for use in the irrigated system. The second factor is the appropriate relief for the installation of these instruments, considering that the slope of up to $13 \%$, or be the classes from A to C (plan to Moderately wavy), to the relief and the strong agriculture. According to Martins (2017) the planing of the relief in some municipalities of this region, has motivated in recent years a greater increase in commercial agriculture, especially the municipality of Jussara, which currently has the second largest irrigated area by central pivot of Goiás. 
Table 4. Municipalities of the Basin of the Araguaia River with central pivot units and total irrigated area

\begin{tabular}{|c|c|c|c|c|c|c|c|c|c|c|c|}
\hline \multirow{2}{*}{ Microbasins } & \multirow{2}{*}{ County } & \multicolumn{5}{|c|}{ Number of Central Pivots } & \multicolumn{5}{|c|}{ Total Area (ha) } \\
\hline & & 2000 & 2003 & 2006 & 2012 & 2016 & 2000 & 2003 & 2006 & 2012 & 2016 \\
\hline \multirow{3}{*}{ Upper Araguaia Basin } & Doverland & 3 & 2 & 3 & 3 & 3 & 291.17 & 174.16 & 291.17 & 291.17 & 291.17 \\
\hline & Aragarças & 0 & 0 & 1 & 0 & 0 & 0 & 0 & 163.53 & 0 & 0 \\
\hline & Mineiros & 2 & 2 & 0 & 0 & 0 & 142 & 216.25 & 0 & 0 & 0 \\
\hline \multirow{4}{*}{ Rio Caiapo } & Caiapônia & 0 & 0 & 0 & 0 & 2 & 0 & 0 & 0 & 0 & 223.86 \\
\hline & Good Garden of Goiás & 1 & 2 & 0 & 0 & 1 & 114.67 & 158.00 & 0 & 0 & 114.67 \\
\hline & Piranhas & 1 & 1 & 1 & 0 & 0 & 34.66 & 34.66 & 35.00 & 0 & 0 \\
\hline & Montes Claros & 1 & 1 & 2 & 2 & 2 & 108.58 & 112.57 & 208.9 & 208.9 & 208.9 \\
\hline Rio Claro-Caiapo & Montes Claros & 7 & 8 & 10 & 11 & 11 & 764.87 & 884.43 & 1098.71 & 1137.73 & 1137.73 \\
\hline \multirow{3}{*}{ clear river } & São João da Paraúna & 0 & 2 & 5 & 5 & 5 & 0 & 196.45 & 295.57 & 295.57 & 295.57 \\
\hline & São Luís dos Montes Belos & 0 & 0 & 0 & 0 & 6 & 0 & 0 & 0 & 0 & 256.05 \\
\hline & Jussara & 3 & 3 & 3 & 3 & 2 & 316.97 & 300.5 & 316.98 & 316.98 & 316.95 \\
\hline \multirow{2}{*}{ Red-Light River } & Jussara & 23 & 23 & 25 & 31 & 65 & 2521,15 & 2654.8 & 2760.47 & 3401.79 & 7406.52 \\
\hline & Britain & 0 & 0 & 1 & 1 & 7 & 0 & 0 & 55.23 & 55.23 & 636.48 \\
\hline \multirow{6}{*}{ Red River } & Britain & 9 & 9 & 9 & 6 & 15 & 1038.34 & 1038.34 & 1123.2 & 774.82 & 1569.09 \\
\hline & Jussara & 40 & 38 & 38 & 38 & 46 & 4577.15 & 4418.09 & 4263.76 & 4182.71 & 4954.03 \\
\hline & Santa Fé de Goiás & 7 & 13 & 13 & 13 & 25 & 810.24 & 1349.75 & 1440.1 & 1440.1 & 2984.14 \\
\hline & Itapirapuã & 8 & 7 & 6 & 4 & 8 & 682.03 & 601.01 & 496.41 & 355.45 & 786.81 \\
\hline & Matrinchã & 13 & 14 & 17 & 9 & 14 & 1278.41 & 1288.08 & 1710.23 & 849.96 & 1224.86 \\
\hline & New Brazil & 1 & 0 & 0 & 0 & 0 & 16.72 & 0 & 0 & 0 & 0 \\
\hline \multirow{4}{*}{ Rio do Peixe } & Matrinchã & 3 & 2 & 3 & 2 & 3 & 236.36 & 160.23 & 247.05 & 165.12 & 236.37 \\
\hline & Aruanã & 1 & 1 & 7 & 9 & 10 & 132.38 & 110.58 & 781.89 & 1085.05 & 1217.33 \\
\hline & Mozarlândia & 3 & 5 & 5 & 3 & 6 & 347.56 & 523.14 & 425.39 & 146.68 & 553.86 \\
\hline & New Crixás & 1 & 3 & 2 & 1 & 2 & 71.37 & 329.89 & 304.74 & 153.18 & 296.62 \\
\hline \multirow{5}{*}{ Rio Crixas } & New Crixás & 5 & 6 & 8 & 10 & 12 & 541.59 & 743.84 & 1000.43 & 1300.03 & 1512.98 \\
\hline & New world & 1 & 1 & 1 & 2 & 2 & 79.94 & 74.64 & 79.94 & 237.52 & 237.52 \\
\hline & Santa Terezinha de Goiás & 0 & 0 & 1 & 2 & 2 & 0 & 0 & 98.07 & 140.59 & 140.59 \\
\hline & Bonopolis & 0 & 0 & 5 & 8 & 13 & 0 & 0 & 461.97 & 736.62 & 1153.42 \\
\hline & Mutunopolis & 1 & 3 & 0 & 0 & 1 & 52.74 & 200.17 & 0 & 0 & 110.45 \\
\hline
\end{tabular}

The average pivot size varied considerably, with pivots ranging from 16.72 to 163.53 ha. The municipalities of Aruanã, Britânia, Nova Crixás, Jussara and Montes Claros presented the highest average values of equipment size, around $119.4 ; 113.5 ; 112.7 ; 112.1$ and 107.0 hectares irrigated by each central pivot. These values are higher than the average of the micro-region of Frutal and Uberlândia (70 hectares) and of the Triângulo Mineiro region with 58.6 hectares central pivot ${ }^{-1}$ (Ferreira et al., 2018). Studies conducted in the State of Rio Grande do Sul by Martins et al. (2016) found the average size of the pivots of 63.66 hectares. 
Table 5. Average size of pivots in the municipalities of the Basin of the Araguaia River

\begin{tabular}{llllll}
\hline \multirow{2}{*}{ County } & \multicolumn{5}{c}{ Average pivot size (ha) } \\
\cline { 2 - 6 } & 2000 & 2003 & 2006 & 2012 & 2016 \\
\hline Doverland & 97.05 & 87.08 & 97.05 & 97.05 & 97.05 \\
Aragarças & 0 & 0 & 163.53 & 0 & 0 \\
Mineiros & 71 & 108.13 & 0 & 0 & 0 \\
Caiapônia & 0 & 0 & 0 & 0 & 74.62 \\
Good Garden of Goiás & 114.67 & 79.00 & 0 & 0 & 114.67 \\
Piranhas & 34.66 & 34.66 & 35.00 & 0 & 0 \\
Montes Claros & 109.18 & 110.78 & 108.97 & 103.59 & 103.59 \\
São João da Paraúna & 0 & 98.22 & 59.11 & 59.11 & 59.11 \\
São Luís do Montes Belos & 0 & 0 & 0 & 0 & 42.67 \\
Jussara & 112.35 & 115.21 & 111.23 & 109.74 & 112.19 \\
Britain & 115.37 & 115.37 & 117.8 & 118.58 & 100,25 \\
Santa Fé de Goiás & 115.75 & 103.83 & 110.78 & 110.78 & 119.35 \\
Itapirapuã & 85.25 & 85.86 & 82.73 & 88.86 & 98.35 \\
Matrinchã & 94.67 & 90.52 & 97.86 & 92.28 & 85.95 \\
New Brazil & 16.72 & 0 & 0 & 0 & 0 \\
Aruanã & 132.38 & 110.58 & 111.70 & 120.56 & 121.73 \\
Mozarlândia & 115.85 & 104.6 & 85.08 & 48.89 & 92.31 \\
New Crixás & 102.16 & 119.30 & 130.52 & 132.11 & 129.26 \\
New world & 79.94 & 74.64 & 79.94 & 118.76 & 118.76 \\
Santa Terezinha de Goiás & 0 & 0 & 98.07 & 70.29 & 70.29 \\
Bonopolis & 0 & 0 & 92.39 & 92.07 & 88.72 \\
Mutunopolis & 52.74 & 6672 & 0 & 0 & 110.45 \\
\hline
\end{tabular}

The increase in the number and irrigated area in certain regions may be related to several factors, which may make viable or unviable the use of central pivot systems, either by favoring production or using equipment and mechanization. Characteristics such as relief, declivity, soil type, urban area, permanent preservation area and water availability are important in existing irrigated areas as well as in new projects (Christofidis, 2013). However, urban areas are not as decisive for the installation of pivots as the characteristics such as soil type, water proximity and slope that can be decisive for the production and installation of pivot systems.

Brazil has a potential of $29.564,000$ hectares of land suitable for the development of sustainable irrigated agriculture. The Center has an area of 4,926 hectares representing $16.7 \%$ of these potential areas (Christofidis, 2013). Knowledge of soil classes and their respective characteristics is indispensable in the understanding of the different forms and intensity, as occurred and the consolidation of mechanized agriculture occurs as well as the implementation of irrigated agriculture in Goiás (Martins, 2017).

The representation reveals that the study area is composed of five classes of soils: Cambisols, Gleissolos, Oxisol, Neosols and Plintosols (Figure 3A). The most prevalent class in the study area is the Oxisol (Table 6). On average 17512.7 ha have pivots located in Oxisol areas, this represents more than $60 \%$ of the total area of pivots. Soils conducive to the development of crops are another indispensable factor, because deep soils and well drained, favor the root development and improve the retention of water in the radicular band, being thus, it observes that the regions where the pivots are concentrated, are the same that present soils with classes of Oxisol (Figure 3A). Moreover, the predominance of pivots in Oxisol areas may also be due to the fact that this type of soil requires lower fertilization costs because it is a more fertile soil, allowing greater investments in the irrigation technique (Pereira Júnior, Ferreira, \& Miziara, 2017). 


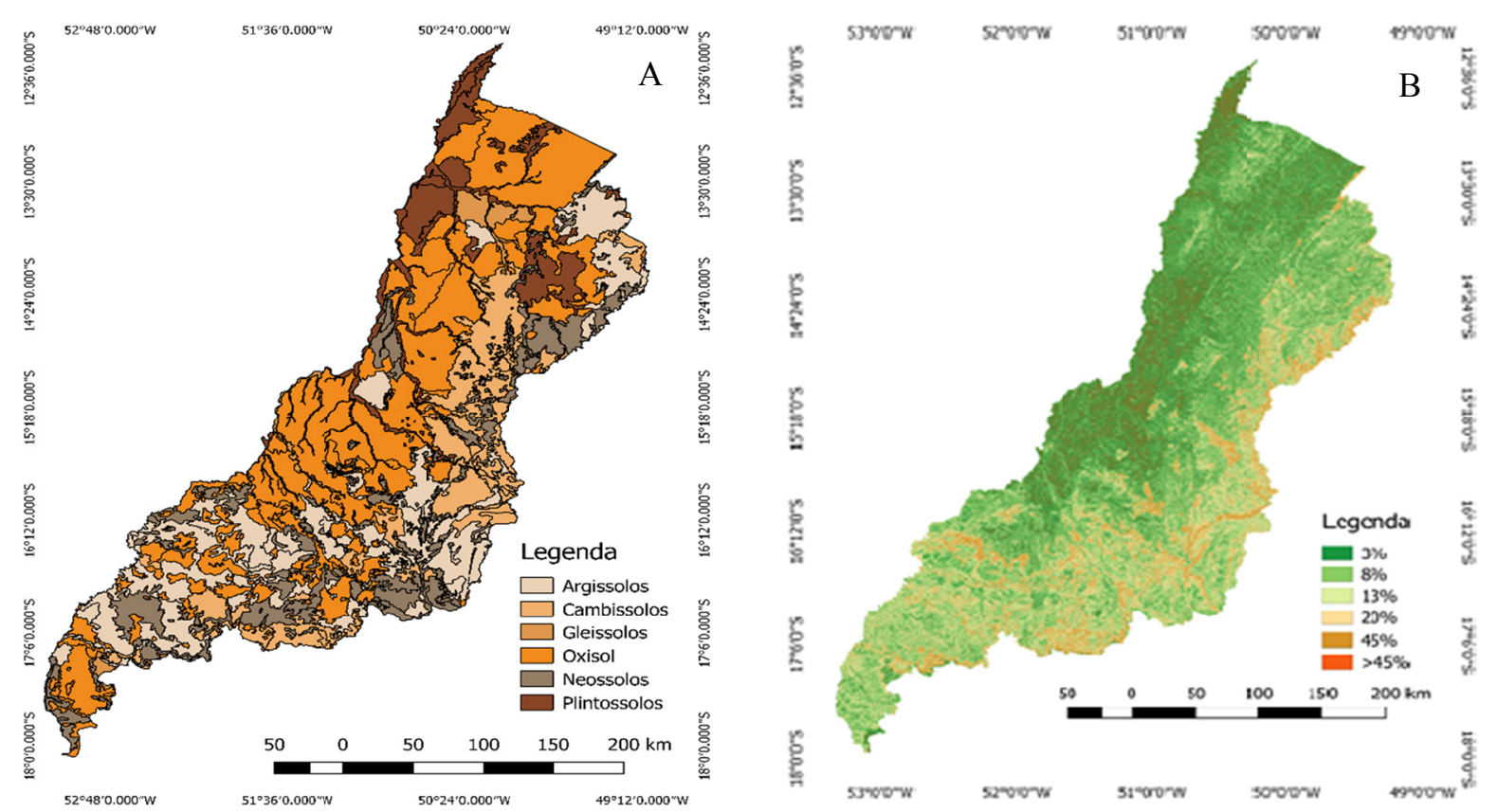

Figure 3. Characteristics of the area of the basin of the tributary of the Araguaia River. A-Soil classes. B-Declivity in percentage

Table 6. Soil classes in the Basin of the Araguaia River tributary in hectares

\begin{tabular}{ll}
\hline Soil class & Area (ha) \\
\hline Oxisol & $3,858,678.20$ \\
Neosol & $1,453,417,84$ \\
Change them & $1,326,542.19$ \\
Gleissolos & $209,502.28$ \\
Plinthsols & $86.8372,96$ \\
Argisols & $1,940,634.98$ \\
\hline
\end{tabular}

The area of the Goian tributary basin of Alto Araguaia presented, for the most part, areas with slopes of 3 to $13 \%$ (flat to moderately undulating relief) (Figure 3B). The declivity is one of the most limiting geoenvironmental factors for the implantation of the central pivot (Martins 2017). According to Lima et al. (2013) it can not be higher than $15 \%$ for areas with central pivot. Most central pivots in Brazil occur in flat to gently undulating terrain (up to $8 \%$ slope), slopes greater than $13 \%$ may limit mechanization in agriculture (Guimarães, Landau, 2014). Places with more pronounced relief limits the evolution of the use of mechanization of the productive process, that is, the agricultural advance in some municipalities can be controlled by the pedological characteristics such as declivity, that can restrict the use of mechanizable equipments (Pereira Júnior, Ferreira, \& Miziara, 2017). The evolution in the central pivot irrigated area and the characteristics such as soil type and slope presented in the region of the Goian tributary of the Alto Araguaia suggest that the region has potential for pivot irrigation.

\section{Conclusion}

The irrigated area and the number of central pivots increased by more than $95 \%$ between 2000 and 2016 .

The central pivots are more concentrated in the central region of the basin of the Goian tributary of Alto Araguaia, in the microbasins of the Rio Vermelho and Vermelho-Claro.

The largest concentration of central pivots occurred in the municipality of Jussara.

The pivots are located predominantly in an Oxisol area with a slope of 3 to $13 \%$.

\section{References}

Aires, U. R. V., Rezende, C. H. S., Silva, J. L. de A., Campos, J. A., \& Santos, C. A. (2017). Capacidade do uso da terra: um estudo de caso em uma microbacia do Rio Piracicaba, MG. Nativa: Pesquisas Agrárias e Ambientais, 5(6), 402-409. https://doi.org/10.5935/2318-7670.v05n06a04 
Christofidis, D. (2013). Água, irrigação e agropecuária sustentável. Revista de Poliitica Agrícola, XXII(1), 115-136.

Darko, R. O., Yuan, S., Hong, L., Liu, J., \& Yan, H. (2015). Irrigation, a productive tool for food security-a review. Acta Agriculturae Scandinavica Section B: Soil and Plant Science, 66(3), 191-206. https://doi.org/ 10.1080/09064710.2015.1093654

FAO (Food and Agriculture Organization). (2016). Brasil será um dos maiores exportadores de alimentos, prevê FAO. Retrieved from http://www.fao.org/brasil/noticias/detail-events/en/c/436508

FAO (Food and Agriculture Organization). (2018). SILVA, J. G. Suplemento fórum mundial da água, publicado pela FAO (nações unidas) março 2018. A água, "o novo petróleo", não tem substituto (pp. 1-6). Retrieved from https://diplomatique.org.br/wp-content/uploads/2018/03/Suplemento-FAO-F\%C3\%B3rum-Mundial-d a-\%C3\%81 gua.pdf

Ferreira, E., Toledo, J. H., Dantas, A. A. A., \& Pereira, R. M. (2011). Cadastral maps of irrigated areas by center pivot in the state of Minas Gerais, using CBERS-2B/CCD satellite imaging. Engenharia Agrícola, 31(4), 771-780. https://doi.org/10.1590/S0100-69162011000400015

Ferreira, D. S., Ribeiro, W. R., Gonçalves, M.S., Pinheiro, A. A., Sales, R. A., \& Reis, E. F. (2018). Cenário da área irrigada por pivô central no Triangulo Mineiro, no Estado de Minas Gerais, Brasil. Nativa, 6(6), 613-618. https://doi.org/10.31413/nativa.v6i6.5864

Flores, P. M., Guimarães, R. F., Júnior, O. A. de C. J., \& Gomes, R. A. T. (2012). Análise multitemporal da expansão agrícola no município de barreiras-Bahia (1988-2008). Campo-Território: Revista de Geografia Agrária, 14(7), 1-19. Retrieved from http://www.seer.ufu.br/index.php/campoterritorio/article/view/14955

Guimarães, D. P., \& Landau, E. C. (2014). Levantamento da Agricultura Irrigada por Pivôs Centrais no Brasil em 2013 (1st ed., p. 40). EMBRAPA (Empresa Brasileira de Pesquisa Agropecuária). Retrieved from http://arquivos.ana.gov.br/imprensa/arquivos/ProjetoPivos.pdf on 20st March 2018

INPE (Instituto Nacional de Pesquisas Espaciais). (2018). Banco de Dados Geomorfométricos do Brasil-TOPODATA. Carta topográfica 12S51, 12S51, 13S51, 13S495 14S51, 14S495, 14S525, 15S51, 15S525, 16S51, 16S54, 16S525, 17S54, 17S525. Retrieved April 11, 2018, from http://www.webmapit. com.br/inpe/topodata?

Kirchner, J. H., Robaina, A. D., Peiter, M. X., Torres, R. R., Mezzomo, W., Ben, L. H. B., ... Pereira, A. C. (2019). Funções de produção e eficiência no uso da água em sorgo forrageiro irrigado. Revista Brasileira de Ciências Agrárias, 14(2), 1-9. https://doi.org/ 10.5039/agraria.v14i2a5646

Landau, E. C., Guimarães, D. P., \& Reis, R. J. (2013). Mapeamento das áreas irrigadas por pivôs centrais no estado de Goiás-Brasil. Retrieved April 13, 2018, from https://ainfo.cnptia.embrapa.br/digital/bitstream/ item/94072/1/Mapeamento-areas.pdf

Landau, E. C., Guimarães, D. P., \& Sousa, D. L. (2014). Caracterização ambiental das áreas de concentração da agricultura irrigada por pivôs centrais na região do MATOPIBA. Anais do Simpósio Regional de Geoprocessamento e Sensoriamento Remoto-GEONORDESTE, Aracaju, Brssil, 13 a 21 Novembro.

Lima, P. H. P., Justina, D. D. D., Lima, L. E. P., Prudente, V. H, R., Souza, C. H. W., \& Mercante, E. (2013) Identificação de áreas aptas à implantação de irrigação por pivô central no município de Unaí-MG utilizando ferramental do SIG. Anais XVI Simpósio Brasileiro de Sensoriamento Remoto-SBSR-INPE, Foz do Iguaçu, PR, Brasil, 13 a 18 de Abril de 2013. https://doi.org/10.13140/2.1.4347.5202

Lopes, M. M., \& Neves, F. F. (2018). A gestão de recursos hidrícos no Brasil: Um panorama geral dos Estados. FACEP Pesquisa: Desenvolvimento e Gestão, 20(3), 237-250.

Martins, J. D., Bohrz, I. S., Fredrich, M., Veronez, R. P., Kunz, G. A., \& Tura, E. F. (2016). Levantamento da área irrigada por pivô central no estado do Rio Grande do Sul. Irriga, 21(2), 300-311. https://doi.org/ 10.15809/irriga.2016v21n2p300-311

Martins, R. A. O. (2017). Agrohidronegócio Do Pivô Central no Estado De Goiás: Expansão, Espacialização e a consequente degradação do subsistema de veredas (Unpublished Doctoral Dissertation, Universidade de Brasília, Brazil).

Mascarenhas, L. M. de A., Ferreira, M. E., \& Ferreira, L. G. (2009). Sensoriamento remoto como instrumento de controle e proteção ambiental: Análise da cobertura vegetal remanescente na bacia do Rio Araguaia. Sociedade \& Natureza, 21(1), 5-18. https://doi.org/10.1590/S1982-45132009000100001 
Pereira Júnior, L. C., Ferreira, N. C., \& Miziara, F. (2017). A expansão da irrigação por pivôs centrais no stado de Goiás (1984-2015). Boletim Goiano de Geografia, 37(2), 323-341. https://doi.org/10.5216/bgg.v37i2. 49158

Qgis Development Team. (2019). QGIS Geographic Information System. Open Source Geospatial Foundation Project. Retrieved from http://www.qgis.org

Ramalho-Filho, A., \& Beek, K. J. (1995). Sistema de avaliação da aptidão agrícola das terras (3rd ed., p. 65). Rio de Janeiro: EMBRAPA-CNPS.

SIEG (Sistema Estadual de Geoinformação do Estado de Goiás). (2019). Download de arquivo shapefile. Retrieved from http://www.sieg.go.gov.br/rgg/apps/siegdownloads/index.html

Silveira, J. M. de C., Sakai, E., Matsura, E., \& Pires, R. C. de M. (2013). Identification of center pivot irrigated areas in tambaú-verde basin by sensor CCD/CBERS. Irriga, 18(4), 721-729. https://doi.org/10.15809/irriga. $2013 \mathrm{v} 18 \mathrm{n} 4 \mathrm{p} 721$

\section{Copyrights}

Copyright for this article is retained by the author(s), with first publication rights granted to the journal.

This is an open-access article distributed under the terms and conditions of the Creative Commons Attribution license (http://creativecommons.org/licenses/by/4.0/). 